\title{
Cell Count and Size in Relation to Fruit Size Among Strawberry Cultivars
}

\author{
Guiwen W. Cheng'and Patrick J. Breen \\ Department of Horticulture, Oregon State University, Corvallis, OR 97331
}

Additional index words. achene, cell division, cell volume, Fragaria $\times$ ananassa

\begin{abstract}
Fruit size, number of receptacle cells, and mean cell size were determined throughout development of secondary fruit of three day-neutral strawberry (Fragaria xananassa Duch.) cultivars grown in a greenhouse. Cells were counted after enzymatic separation of receptacle tissue, and mean cell volume was estimated from cell count and receptacle tissue volume. Size of mature fruit was small $(3.8 \mathrm{~g})$ in 'Tillikum', medium (11.5 g) in 'Tristar', and large (15.6 $\mathrm{g})$ in 'Selva'. Fruit size was correlated with the number of achenes per berry. Mature fruit of 'Tillikum' had a lower fruit fresh weight per achene and lower achene population density (achenes per square centimeter) than the larger-fruited cultivars. The average number of cells per mature fruit was $0.72 \times 10^{6}, 1.96 \times 10^{6}$, and $2.94 \times$ $10^{6}$ for 'Tillikum', 'Tristar', and 'Selva', respectively. The relative difference among cultivars in the number of receptacle cells was established by the time of anthesis. In all cultivars, cell division was exponential for 10 days following anthesis and ceased by the 15th day. Mean cell volume increased slowly during active cell division, but rose rapidly and linearly for 10 days after cell division halted. Mean cell volume of all cultivars increased $>12$-fold after anthesis and was $\approx 6 \times 10^{6} \mathrm{~mm}^{3}$ in mature fruit. The genotypic variation in the size of mature fruit was not the result of large differences in either duration of cell division after anthesis or mean cell volume, but rather was primarily due to differences in the number of receptacle cells established by anthesis.
\end{abstract}

Strawberry genotypes show a wide range in fruit size (Moore et al., 1970; Øydvin, 1984). This variation could result from differences in the number of cells making up the receptacle, cell volume, and intercellular volume. In other fleshy fruits, differences in either cell count or cell volume, or both, are responsible for size variation resulting from dissimilar genetic makeup, environmental conditions, and crop management practices (Coombe, 1976; Harris et al., 1968; Sinnott, 1939; Smith, 1950). The relative contribution of the components of fruit size is species and cultivar dependent (Bollard, 1970; Coombe, 1976). The contributions of cell volume and cell count to genotypic differences in strawberry fruit size are unknown, although such information would be helpful in interpreting fruit growth patterns and size and quality characteristics at maturity. For example, cultivar differences in cell size are a factor in the degree of tissue disorganization observed in frozen-thawed strawberry fruit (Armbruster, 1967).

Timing, duration, and rate of cell division and enlargement are distinct characteristics of fruit type (Bollard, 1970; Coombe, 1976). Cells of mature fleshy fruits are the product of cell divisions that occur before and for sometime after anthesis (Coombe, 1976). Differences in duration of postanthesis cell division contribute to genotypic variation in number and size of cells of mature fruit. The length of the cell division period in many fleshy fruits is well documented (Bollard, 1970), but it is uncertain in strawberry. Havis (1943) reported that cell division in the cortex of strawberry fruit essentially ceases by anthesis. However, Knee et al. (1977) found that the number of cells of 'a strawberry fruit continues to increase for more than a week following petal fall.

Changes in cell count and size of developing strawberry fruit have been examined (Knee et al., 1977; Neal, 1965; Szczesniak and Smith, 1969), but there is little information on genotypic

Received for publication 28 Oct. 1991. Accepted for publication 26 May 1992. Oregon Agricultural Experiment Station Technical Paper no. 9705. The cost of publishing this paper was defrayed in part by the payment of page charges. Under postal regulations, this paper therefore must be hereby marked advertisement solely to indicate this fact.

'Present address: University of California, Kearney Agricultural Center, 9240 S. Riverbend Ave., Parlier, CA 93648. comparison of cell size. Darrow (1966) noted that cells of the fruit cortex in the cultivated strawberry are four to five times as wide at those of the smaller-fruited Fragaria vesca.

Growth of the strawberry receptacle depends on auxin supplied by developing achenes on the berry surface (Nitsch, 1950). Final fruit size is correlated with the number of achenes per berry, which is determined during floral development. Much of the variation in fruit size among strawberry cultivars can be accounted for by differences in achene count (Moore et al., 1970; Øydvin, 1984), although size is also affected by environmental and internal factors (Strik and Proctor, 1988). Each achene may be envisioned as associated with a contiguous group of fruit cells whose division and enlargement increases fruit size. This expansion decreases the number of achenes per unit berry surface during fruit development (Abbott et al., 1970; Forney and Breen, 1985). Conversely, fruit weight per achene increases as the fruit enlarges, and it may be a genotypic character that reflects differences in auxin release, tissue responsiveness, and photoassimilate supply.

The main objectives of this study were to determine the duration of cell division and the contribution of cell count and size to differences in fruit size among three strawberry cultivars. In addition, achene count and spacing were measured to determine their relationship to the number and size of receptacle cells.

\section{Materials and Methods}

Certified nursery plants of day-neutral cultivars Tillikum, Tristar, and Selva were grown in 3.8-liter pots in 1 soil : 1 coarse sand : 1 peat (by volume) in a greenhouse at $21 / 17 \mathrm{C}$ (day/night). High pressure sodium lamps $(175 \pm 25$ $\left.\mu \mathrm{mol} \cdot \mathrm{m}^{-2}-\mathrm{s}^{-1}\right)$ provided a $16 \mathrm{~h}$ photoperiod. Emerging runners and flower buds were removed for $\approx 40$ days after planting to establish plants of desired size. Flowers were hand-pollinated at anthesis, when pollen was first visible, to improve uniformity of fruit development. To ensure sufficient sample size and uniformity, only secondary fruit were collected for analysis. Flower buds at inferior rankings were removed when secondary flowers were pollinated.

Abbreviation: DAA, days after anthesis. 
Fruit, 10 to 15 per cultivar, were harvested at anthesis and subsequently at 5-day intervals until ripe. After removal of sepals and pedicel, the fruit was weighed and diameter at the greatest shoulder width measured with a Vernier caliper. Achenes on each intact fruit were counted and classified either as normally or poorly developed (aborted), based on size and color. Each achene was marked with a pen as it was counted. The volume of receptacle tissue, not that of intact fruit, was determined by water displacement after first slicing fruit in half lengthwise to avoid difficulty with voids in the pith. Tween 80 (1 drop per $10 \mathrm{ml}$ ) was added to prevent bubbles from forming on the tissue surface. Because of small receptacle volumes at anthesis, volume measurements were initiated 5 days after anthesis (DAA). Expansion of receptacle tissue was quantified by changes in the population density of achenes (achenes per square centimeter), which was measured by averaging the number of achenes visible in a circular $0.5 \mathrm{~cm}^{2}$ aperture held against the berry at two random locations in the shoulder region.

To determine cell count per fruit, 3-mm-thick slices of fruithalves were placed in an enzyme digestion solution under reduced pressure for $1 \mathrm{~h}$ and then gently shaken overnight in a water bath at $25 \mathrm{C}$. When necessary, clumps of tissue were agitated very gently with a glass rod to help cell separation. The enzyme digestion solution consisted of pectinase (EC 3.2.1.15) (2 $\mathrm{mg} \cdot \mathrm{ml}^{-1}$, Sigma, St. Louis), cellulase (EC 3.2.1.4) (1 $\mathrm{mg} \cdot \mathrm{ml}^{-1}$, Sigma), and sucrose $\left(60 \mathrm{mg} \cdot \mathrm{ml}^{-1}\right)$ in a buffer of 5 m M MES (2-[N-morpholino]ethanesulfonic acid), $0.7 \mathrm{~m} \mathrm{Na-}$ $\mathrm{H}_{2} \mathrm{PO}_{4}$, and $6 \mathrm{mM} \mathrm{CaCl}_{2}(\mathrm{pH}$ 5.5). Before counting of cells, an aliquot of digestion mixture was diluted with buffer, without the digestion enzymes, to a population of $\approx 5000$ cells per milliliter and several drops of aqueous neutral red added. Cell rupture was assumed to be minimal since cell shrinkage was commonly observed. Cells were counted in eight randomly selected 2.2-mm squares under a microscope using a Batch (Sedgewick Rafter) counting chamber $(20 \times 50 \times 1 \mathrm{~mm}, 1 \mathrm{ml}$ capacity). In evaluating the apparatus, counts of suspensions of 'Tillikum' pollen differed only by $7 \%$ from those made with a hemocytometer. Cell counts were made on three aliquots of each digest and the number of cells per fruit calculated from the total volume of the digestion mixture. Mean cell volume $\left(\mu \mathrm{m}^{3}\right)$ was calculated from measurements of cell count and fruit tissue volume. Since receptacle tissue is made up of diverse cell sizes, and our calculations made no allowance for variations in intercellular volume, estimated cell volumes were only an approximation.

For anatomical examination, fruit at selected stages were sliced and fixed in FAA, dehydrated in a graded ethanol series, embedded in Paraplast, and $10 \mathrm{pm}$ sections cut with a microtome. Sections were mounted, stained with safranin and fast green, and examined by light microscopy.

\section{Results}

Fruit growth. Size of secondary fruit of the three cultivars differed throughout development and at maturity, as shown by differences in fruit diameter (Fig. 1A), fresh weight, and fruit tissue volume (Fig. 1B). Fruit weight at anthesis was $0.034 \mathrm{~g}$ in 'Tillikum', $0.075 \mathrm{~g}$ in 'Tristar', and $0.178 \mathrm{~g}$ in 'Selva'. Gain in fresh weight was greatest between 15 and 20 DAA, and growth of 'Tillikum' and 'Tristar' fruit essentially ceased at $\approx 25$ DAA. Growth of 'Selva' fruit may also have stopped at that time, but because of an error it was not harvested at 30 DAA. Fresh weight of mature fruit at 25 DAA was $3.8 \mathrm{~g}, 11.5 \mathrm{~g}$, and $15.6 \mathrm{~g}$ for 'Tillikum', 'Tristar', and 'Selva', respectively. Com-
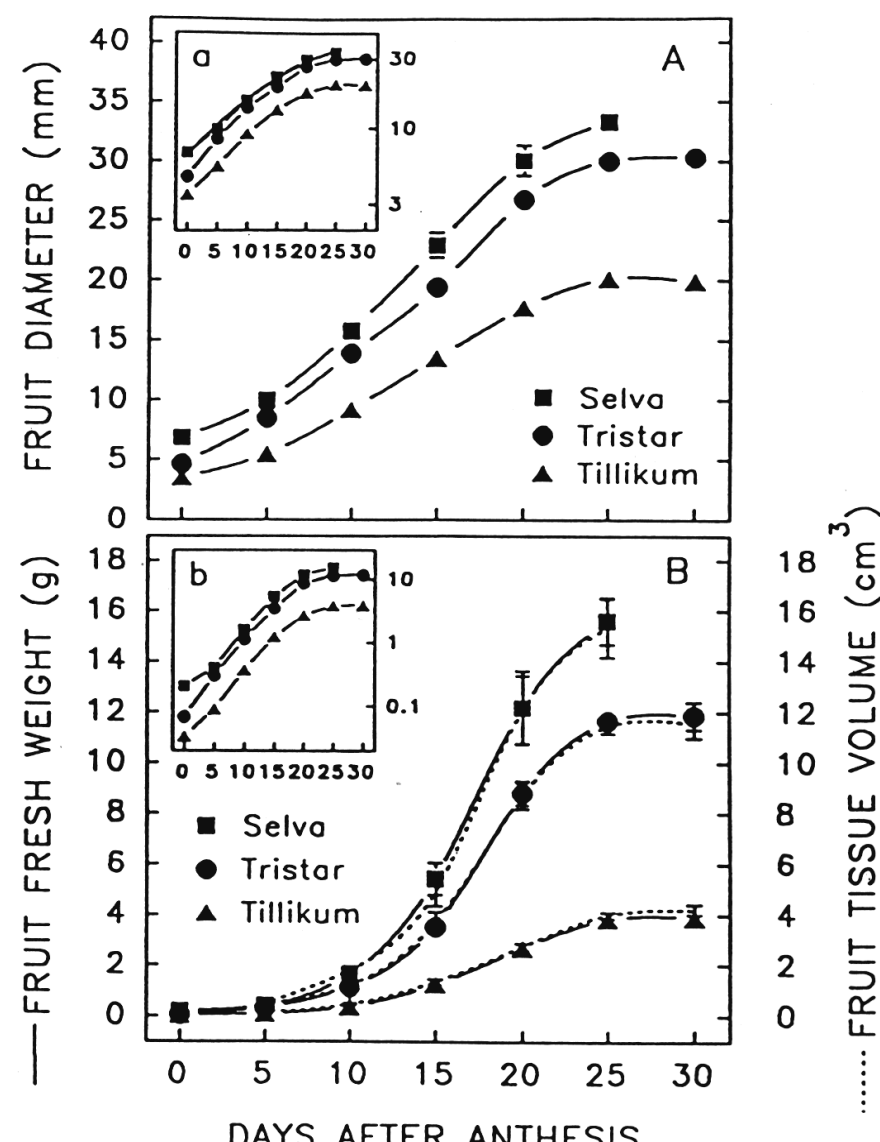

Fig. 1. Developmental increase in (A) diameter and (B) fresh weight and volume of secondary fruit of three strawberry cultivars. Vertical bars represent $\pm \mathrm{SE}$, bars smaller than symbols are not shown. Inserts show increase in (a) diameter and (b) fresh weight on a logarithmic scale.

parable fruit tissue volumes were 4.0, 11.3, and $15.3 \mathrm{~cm}^{3}$ (Fig. 1B). The correlation between fresh weight and receptacle volume was highly significant ( $R 2=0.974$ to $0.994, P<0.01$ ) throughout fruit development. Fruit growth in terms of diameter (Fig. la), fresh weight (Fig. lb), and fruit tissue volume (data not shown) were nearly exponential in all cultivars during the first 2 weeks of development.

Fruit of 'Tillikum' averaged 100 achenes, whereas berries of 'Tristar' and 'Selva' had 220 and 315 achenes, respectively (Table 1). The proportion of developed achenes was higher in the larger fruited cultivars. Across all cultivars, there was a significant correlation $(P<0.01)$ between fruit fresh weight at anthesis and total achenes $\left(R^{2}=0.687\right)$ and between fresh weight at 25 DAA and total $\left(R^{2}=0.911\right)$ and developed $\left(R^{2}\right.$ $=0.843$ ) achenes. At the start of rapid fruit growth at 10 DAA, there were 23 to 25 achenes per square centimeter fruit surface. However, achene density decreased sharply in all cultivars over the next 10 days (data not shown). Minimum achene population density was attained by 25 DAA and the value for 'Tillikum' was significantly lower than that for 'Tristar' or 'Selva' (Table 1). Fruit fresh weight per total achene was similar in mature fruit of 'Tristar' and 'Selva', but significantly less in 'Tillikum' (Table 1). Fresh weight per developed achene was also significantly lower in 'Tillikum' than in 'Tristar'.

Cell division and cell enlargement. The number of cells per fruit differed among genotypes throughout development (Fig. 


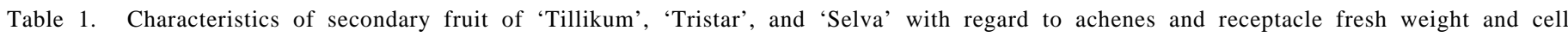
number.

\begin{tabular}{|c|c|c|c|c|c|c|c|c|c|}
\hline \multirow[b]{3}{*}{ Cultivar } & \multirow{2}{*}{\multicolumn{2}{|c|}{ Achenes per fruit $^{2}$}} & \multirow{3}{*}{$\begin{array}{c}\text { Developed } \\
\text { achenes } \\
\%\end{array}$} & \multirow{3}{*}{$\begin{array}{l}\text { Achene density } \\
\left(\text { achenes/cm }{ }^{2}\right)\end{array}$} & \multirow{2}{*}{\multicolumn{2}{|c|}{$\begin{array}{l}\text { Receptacle fresh wt }(\mathrm{mg}) \\
\text { per achene }\end{array}$}} & \multicolumn{3}{|c|}{ No. receptacle cells } \\
\hline & & & & & & & \multirow{2}{*}{\multicolumn{2}{|c|}{ Per $\mathrm{g}$ fresh $\mathrm{wt}$}} & \multirow{2}{*}{$\begin{array}{l}\text { Per total no. } \\
\text { of achenes }\end{array}$} \\
\hline & Total & Developed & & & Total & Developed & & & \\
\hline Tillikum & $100 \pm 4 a^{x}$ & $69 \pm 4 a$ & 69 & $9.2 \pm 0.3 \mathrm{a}$ & $39 \pm 2 a$ & $53 \pm 3 a$ & 190,000 & $\pm 8,740 \mathrm{a}$ & $7,270 \pm 381 \mathrm{a}$ \\
\hline Tristar & $220 \pm 4 b$ & $172 \pm 4 b$ & 78 & $10.8 \pm 0.3 \mathrm{~b}$ & $51 \pm 2 b$ & $71 \pm 3 b$ & 170,000 & $\pm 1,025 \mathrm{a}$ & $8,470 \pm 449 a$ \\
\hline Selva & $315 \pm 5 c$ & $243 \pm 5 c$ & 77 & $10.7 \pm 0.3 \mathrm{~b}$ & $53 \pm 1 \mathrm{~b}$ & $65 \pm 4 a b$ & 173,000 & $\pm 1,664$ a & $9,080 \pm 813 a$ \\
\hline
\end{tabular}

${ }^{2}$ Data of all harvested fruit beginning 10 DAA (mean \pm SE).

${ }^{y}$ Mature fruit at 25 DAA (mean $\pm \mathrm{SE}$ ).

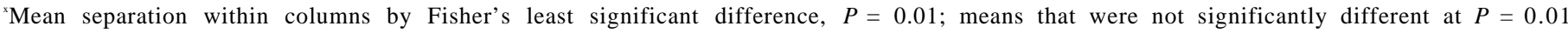
also were not at $P=0.05$.

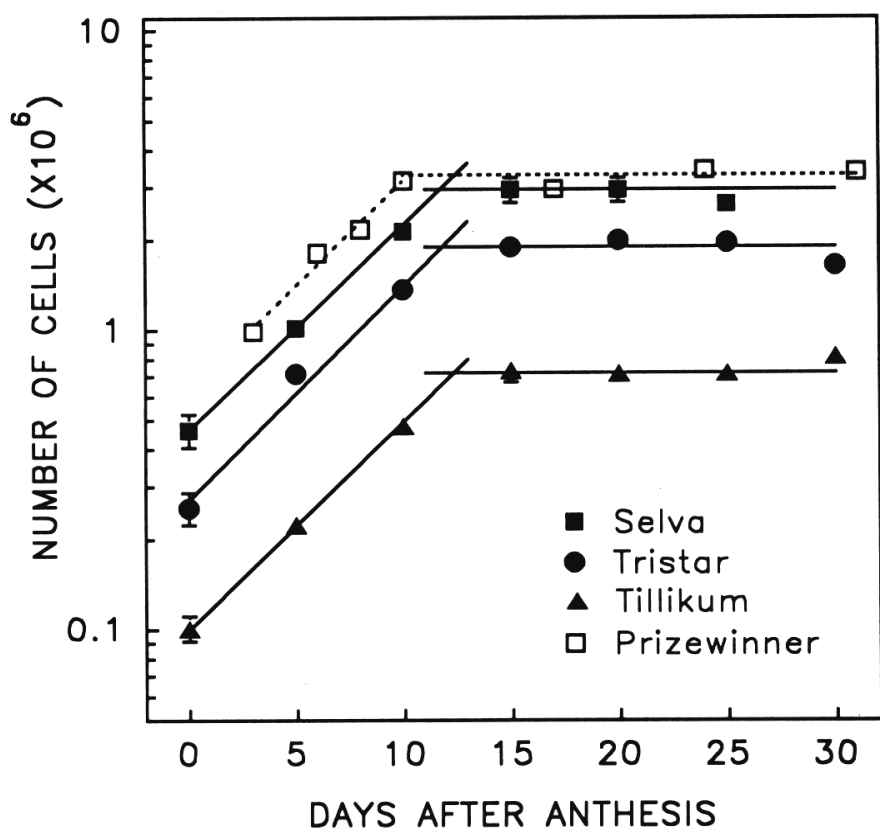

Fig. 2. Postanthesis changes in number of receptacle cells, plotted on a logarithmic scale, of secondary fruit of three strawberry cultivars. Data from Knee et al. (1977) on mean receptacle cell numbers in 'Prizewinner' fruit plotted for comparison after adjustment of 0 days after petal fall to 3 days after anthesis.

2). Data from Knee et al. (1977) with field-grown fruit of 'Prizewinner' strawberry are included for comparison. Cell count at anthesis was approximately $0.10 \times 10^{6}, 0.26 \times 10^{6}$, and 0.46 $\times 10^{6}$ for 'Tillikum', 'Tristar', and 'Selva', respectively. In all three cultivars, cells divided at an exponential rate for 10 days following anthesis, but division ceased by 15 DAA. Due to differences in the base cell count at anthesis, the average number of receptacle cells produced per day during the 10 days following anthesis differed among cultivars, $\approx 38,000$ in 'Tillikum', 119,000 in 'Tristar', and 168,000 in 'Selva'. Dividing cells were observed in flesh tissue of fruit sampled postanthesis (Fig. $3 \mathrm{~A})$. The number of cells per mature fruit was $0.72 \times 10^{6} \mathrm{in}$ 'Tillikum', $1.96 \times 10^{6}$ in 'Tristar', and $2.94 \times 10^{6}$ in 'Selva'. Cultivars showed similar developmental changes in number of cells per gram fresh weight of receptacle (Fig. 4), although 'Tillikum' tended to have a higher value at maturity (Table 1). After cell division ceased, mean cell count per fruit across all cultivars was correlated with the number of total $\left(R^{2}=0.897\right.$ $P<0.01)$ and developed $\left(R^{2}=0.870, P<0.01\right)$ achenes.

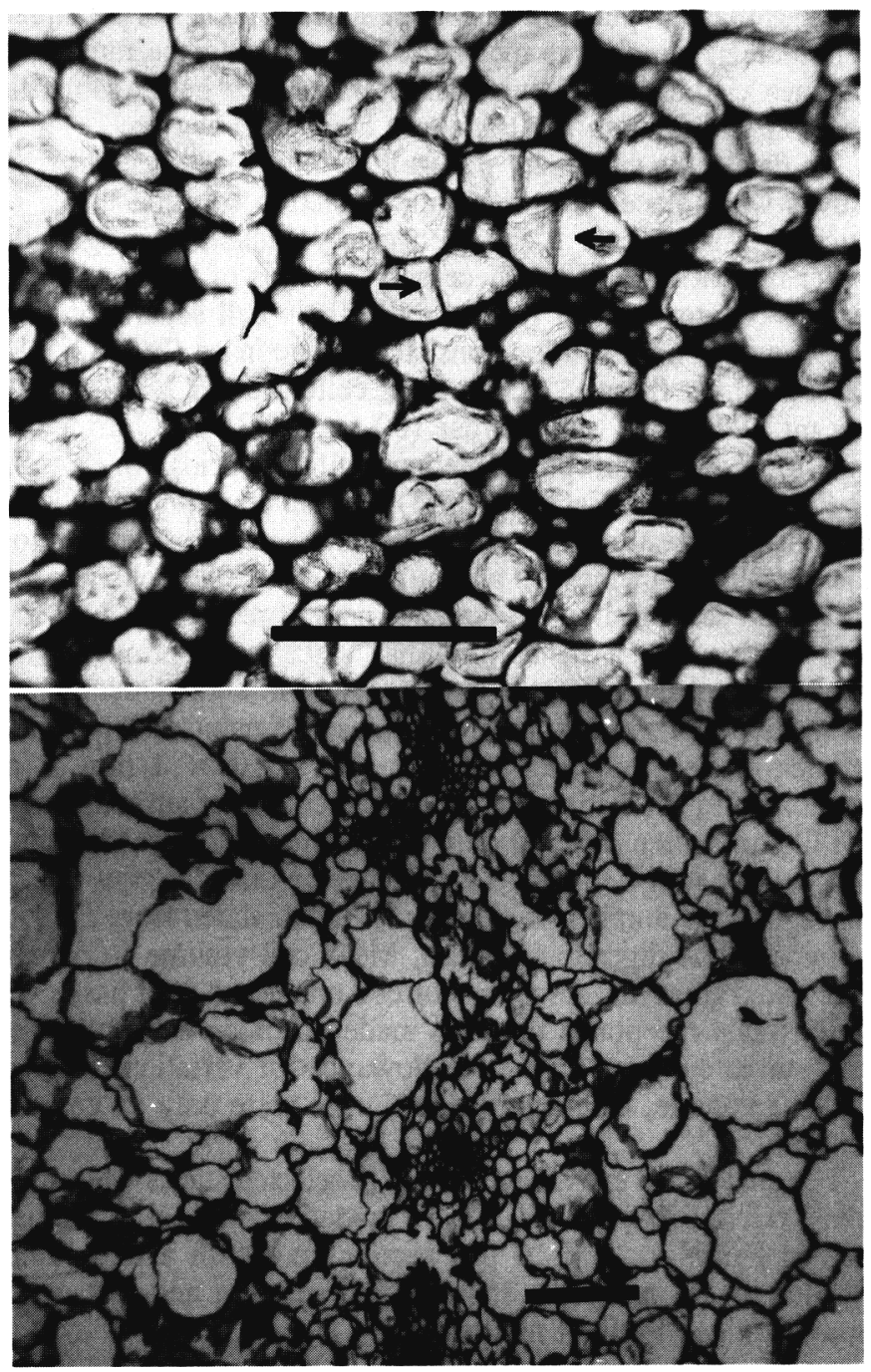

Fig. 3. Light photomicrographs of receptacle tissue in secondary fruit of strawberry. (A) Cross section of the cortex of 'Tillikum' 5 DAA. Arrows identify dividing cells. Bar $=50 \mu \mathrm{m}$. (B) Cross section of pith (left) and cortex (right) in the vicinity of the vascular ring of 'Tristar' 25 DAA. Bar $=100 \mu \mathrm{m}$.

The number of receptacle cells per achene was lowest in 'Tillikum', but differences among cultivars were not significant (Table 1).

Average volume of receptacle cells increased slowly in each of the three cultivars during the cell division period, but showed a very rapid rise as cell division ceased (Fig. 4). Cultivar did 


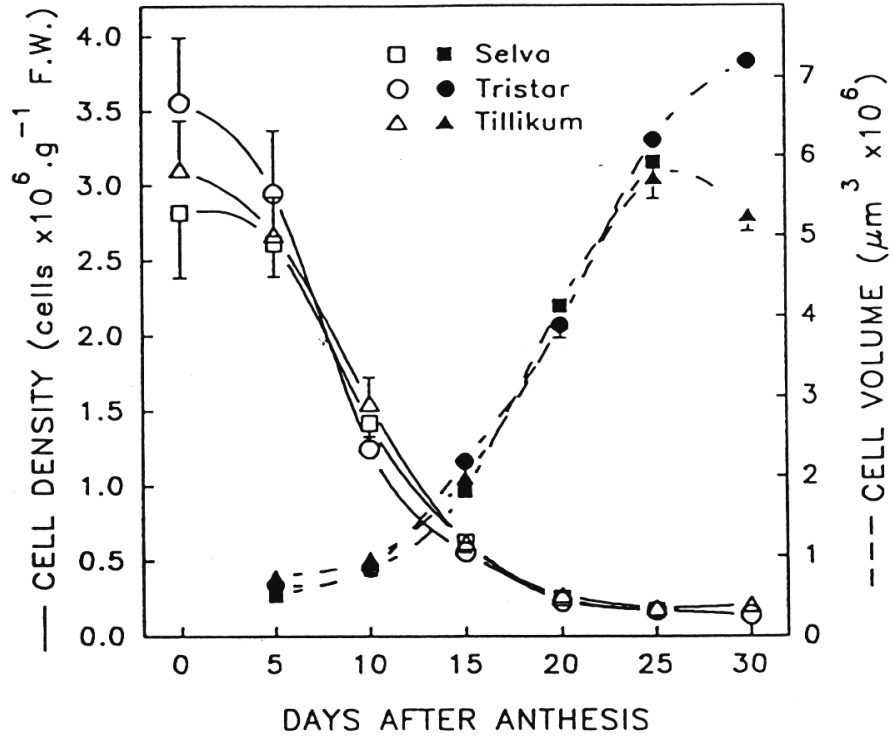

Fig. 4. Developmental changes in number of cells per gram fresh weight of receptacle and receptacle cell volume in secondary fruit of three strawberry cultivars. Vertical bars represent \pm SE, bars smaller than symbols not shown.

not have a significant effect on average cell volume, which on 25 DAA was $\approx 6 \times 10^{6} \mu \mathrm{m}^{3}$. This volume was $\approx 12$ times larger than the mean cell volume at five DAA. The apparent differences in cell volume among cultivars at 30 DAA are attributed to errors in counting cells of soft, ripe fruit.

Cell enlargement in the fruit pith and cortex was not synchronous. Cells in the pith were several times larger than those in the cortex at anthesis, but cortical cells then expanded more rapidly. At 10 DAA, the difference in overall cell size between the two parts of the fruit was much less. A large range of cell sizes was observed in both tissues, and diversity increased during fruit growth (Fig. 3B). Cortical cells in regions midway between parallel vascular bundles became much larger than those near the bundles.

\section{Discussion}

Fresh weight of ripe secondary fruit of 'Selva' was four times that of 'Tillikum' and 1.3 times that of 'Tristar'. Correspondingly, cell count in 'Selva' fruit was four and 1.5 times that of 'Tillikum' and 'Tristar', respectively. Thus, the number of cells per gram fruit fresh weight was similar in these cultivars. Since the mean volume of fruit cells was similar among the three cultivars, cell count per fruit clearly was the predominant component of genotypic variation in fruit size, assuming that cultivar differences in intercellular volume of receptacle tissue were small.

The results from counting separated cells and microscopic examination of receptacle tissue verify that there is active postanthesis cell division in strawberry fruit. Comparing cell counts at anthesis with those of mature fruit in the three cultivars indicated that $>80 \%$ of the receptacle cells were formed after anthesis. This result agrees with the results of Knee et al. (1977) that $\approx 70 \%$ of the receptacle cells of 'Prizewinner' are formed after petal fall, which probably occurs 3 to 4 days after anthesis. In contrast, Havis (1943) claimed that after anthesis <10\% and $20 \%$ of the growth of fruit cortex and pith, respectively, was due to cell division. His low estimate of cell division was derived from relative changes in cross sectional width of the pith and cortex and the average width of the largest cells. Knee et al. (1977) suggested that this method is probably unsuitable since it overlooks the increase of intercellular space in the pith during fruit development. The wide diversity of cell sizes in receptacle tissue may have contributed to the underestimation of the length of the cell division period by Havis, since he used the average width of the largest cells to calculate number of cells per fruit cross section.

The total number of fruit cells produced postanthesis is a function of the number of cells present at anthesis and the duration and rate of cell division. Duration of cell division after anthesis in the three cultivars was between 10 and 15 days, or $\approx 30 \%$ to $50 \%$ of the length of the 30 -day fruit growth period. This period is comparable to the relative cell division period of other fleshy fruits (Bollard, 1970). Cessation of cell division early in the second week following anthesis may be a general characteristic of strawberry fruit, since cell division in fruit of field-grown 'Prizewinner' also stopped at $\approx 10$ days following anthesis (Fig. 2). The data graphed in Fig. 2 suggests that the length of postanthesis cell division among the cultivars differed by a few days, with the small-fruited 'Tillikum' cultivar showing the longest period of cell division. However, the sampling interval of 5 days was not frequent enough to preciscely identify when cell division halted in developing fruit.

The relative number of fruit cells in 'Tillikum', 'Tristar', and 'Selva' was, respectively, 1.0:2.5:4.6 at anthesis and 1.0:2.5:4.0 at $15 \mathrm{DAA}$, by which cell division had ceased. Since the duration and rate of cell division and mean cell size were similar among genotypes, the potential cultivar variation in size of mature fruit was established by differences in the base cell count at anthesis. The establishment of genotypic variation in fruit size in strawberry at anthesis is similar to that reported for tomato (Lycopersicon esculentum Mill.) (Owen and Aung, 1990), but contrasts with the causes of size differences in other species. For example, fruit size variation among apple (Malus domestica Borkh.) cultivars primarily results from differences in the abundance of cell division after pollination (Smith, 1950). Ovaries of large-sized pumpkin (Cucurbitu pepo L.) genotypes have many cells at flowering, but variation in fruit size usually results from differences in both the number and size of cells (Sinnott, 1939).

Rapid cell expansion, after cell division ceased, is reflected in the sharp rise in mean fruit cell volume at 10 DAA. Knee et al. (1977) found that the mean diameter of receptacle cells measured in transverse sections increased exponentially until late in fruit development. The large diversity in receptacle cell sizes found in this study, especially in the cortex, showed that all cells did not expand equally. Szczesniak and Smith (1969) observed distinct groups of cell sizes in fruit of 'Sparkle' strawberry; cells ranged from widths $<100 \mu \mathrm{m}$ to lengths $>800 \mu \mathrm{m}$. Neal (1965) reported that the average dimensions of cortical parenchyma cells were $250 \times 150 \mathrm{pm}$ in mature fruit of 'Cambridge Favorite' and 'Huxley' strawberries. A cell of such dimensions in an ideal cylindrical shape has a volume of $4.4 \mathrm{x}$ $10^{6} \mu \mathrm{m}^{3}$, and as a solid rectangle, $5.6 \times 10^{6} \mu \mathrm{m}^{3}$, which is similar to the estimated mean cell volume at 25 DAA in the three cultivars used in this study (i.e., $6 \times 10^{6} \mu \mathrm{m}^{3}$ ).

The similarity among the three cultivars in the pattern of cell division and mean receptacle cell volume could be a result of their analogous genetic backgrounds. Although the cultivars used in this study are products of strawberry breeding programs in diverse regions of the United States (i.e., Pacific Northwest, mid-Atlantic, and California), the day-neutral trait of each can 
be traced to the breeding selection Cal 65.65-601, which is a parent of 'Tillikum' (Sjulin and Barritt, 1984) and grandparent of 'Tristar' (Draper et al., 1981) and 'Selva' (D.V. Shaw, personal communication).

In addition to genetic makeup, the number of cells of strawberry fruit is likely influenced by growth conditions and management practices, as has been shown with fruit of other species (Bergh, 1985; Harris et al., 1968; Smith, 1950). However, it is surprising that the number of cells in mature field-grown 'Prizewinner' fruit, with a fresh weight of only $8.7 \mathrm{~g}$ (Knee et al., 1977), is similar to that of greenhouse-grown 'Selva' fruit that averaged $15.6 \mathrm{~g}$ (Fig. 2). As a result, mature 'Selva' fruit had half the number of cells per gram fruit weight as that of 'Prizewinner', calculated at 382,000 cells per gram from data of Knee et al. (1977). This difference could be a genotypic effect as well as a reflection of dissimilar growth environments. Grape (Vitis vinifera L. Cv. Sultana) berries from field-grown plants were found to have twice as many pericarp cells as greenhouse-grown berries (Harris et al., 1968). Methodology may also have contributed to the apparent dissimilarity in cells per gram fruit fresh weight in 'Prizewinner' and 'Selva', since somewhat different procedures were used by us and Knee et al. (1977) to separate and count receptacle cells.

The effect of achenes on strawberry fruit size, even across genotypes, is accumulative (Moore et al., 1970). Øydvin (1984) found that $93 \%$ of the variation in size of secondary fruit from 13 strawberry genotypes is accounted for by the total number of achenes per fruit. Among the three genotypes used in this study, the comparable figure was $91 \%$ for total achenes or $84 \%$ when only developed achenes were considered. During strawberry flower bud formation, the potential achenes (pistils) are initiated in an orderly sequential pattern (Sattler, 1973) and their number is linked with receptacle size (Takeda et al., 1990). Therefore, receptacle dimensions at anthesis, which also reflect the number of receptacle cells, should be a good indication of final fruit size, assuming normal development. Achene population density (achene per square centimeter) is strongly influenced by environmental conditions during berry growth (Webb et al., 1974), but the minimum value recorded at fruit maturity may well be genotype-dependent (Strik and Proctor, 1988; Wenzel and Smith, 1974). The significantly lower achene density in mature berries of 'Tillikum' than 'Tristar' and 'Selva' could reflect greater fruit expansion in this small-fruited cultivar (Webb et al., 1974), even though it had the highest proportion of poorly developed achenes. Differences among strawberry genotypes in achene density at fruit maturity might also be a consequence of differences established during floral development.

Mean fruit weight per achene in strawberry varies with cultivar (Janick and Eggert, 1968; Moore et al., 1970; Strik and Proctor, 1988; Webb et al., 1974), and is undoubtedly associated with fruit size and shape. For spherical shaped berries, an increase in linear dimensions of the receptacle would increase surface area and volume in a quadratic and cubic manner, respectively, thereby increasing the volume (or weight) to surface ratio of the berry and fruit weight per achene (Abbott et al., 1970). Fruit shape could modify both ratios. Differences in fruit size and shape were likely responsible for lower fruit weight per achene in 'Tillikum' compared to the other cultivars. The smaller 'Tillikum' fruit had a globoseconic shape whereas berries of 'Tristar' and, especially, 'Selva' were more wedge-shaped. Surprisingly, the lower fruit weight per achene in mature 'Tillikum' berries was not reflected in a significantly lower number of receptacle cells per achene or cell size, possibly because genotypic differences in the amount of intercellular space confounded estimates of cell size and/or our cell counting procedures lacked sufficient precision.

In summary, during the 10-day period following anthesis, growth in strawberry receptacles was primarily due to an increase in number of cells, accompanied by only a relatively small increase in mean cell size. When cell division ceased, between 10 and 15 DAA, enlargement of receptacle cells increased rapidly. Fruit of 'Tillikum', 'Tristar', and 'Selva' differed in size over a 4-fold range, but the duration and relative rate of cell division and mean cell volume were similar. Variation in size of receptacle tissue among the three cultivars was due to differences in cell count, which were established by anthesis. Fruit fresh weight per achene was lower in 'Tillikum' than the other cultivars, but genotype did not have a significant effect on the number of receptacle cells per achene.

\section{Literature Cited}

Abbott, A.J.. G.R. Best, and R.A. Webb. 1970. The relation of achene number to berry weight in strawberry fruit. J. Hort. Soc. 45:215-222.

Armbruster, G. 1967. Cellular and textural changes in three varieties of strawberries as a result of pre-freezing treatments. Proc. Amer. Soc. Hort. Sci. 91:876-880.

Bergh, 0. 1985. Effect of the previous crop on cortical cell number of Malus domestica cv. Starking Delicious apple flower primordia, flowers and fruit. S. African J. Plant Soil 2:191-196.

Bollard, E.G. 1970. The physiology and nutrition of developing fruits, vol. 1, p. 387-427. In: A.C. Hulme (ed.). The biochemistry of fruits and their products. Academic Press, New York.

Coombe, B.G. 1976. The development of fleshy fruits. Annu. Rev. Plant Physiol. 27:507-528.

Darrow, G.M. 1966. The strawberry. Holt, Rinehart, \& Winston, New York.

Draper, A.D., G.J. Galletta, and H.J. Swartz. 1981. 'Tribute' and 'Tristar' everbearing strawberries. HortScience 16:794-795.

Forney, C.F. and P.J. Breen. 1985. Growth of strawberry fruit and sugar uptake of fruit discs at different inflorescence positions. Scientia Hort. 27:55-62.

Harris, J.M., P.E. Kriedemann, and J.V. Possingham. 1968. Anatomical aspects of grape berry development. Vitis 7:106-119.

Havis, A.L. 1943. A developmental analysis of the strawberry fruit. Amer. J. Bot. 30:311-314.

Janick, J. and D.A. Eggert. 1968. Factors affecting fruit size in the strawberry. Proc. Amer. Soc. Hort. Sci. 93:311-316.

Knee, M., J.A. Sargent, and D.J. Osborne. 1977. Cell wall metabolism in developing strawberry fruits. J. Expt. Bot. 28:377-390.

Moore, J.N., G.R. Brown, and E.D. Brown. 1970. Comparison of factors influencing fruit size in large-fruited and small-fruited clones of strawberry. J. Amer. Soc. Hort. Sci. 95:827-831.

Neal, G.E. 1965. Changes occurring in the cell walls of strawberries during ripening. J. Sci. Food Am. 16:604-611.

Nitsch, J.P. 1950. Growth and morphogenesis of the strawberry as related to auxin. Amer. J. Bot. 37:211-215.

Gwen, H.R. and L.H. Aung. 1990. Genotypic and chemical influences on fruit growth of tomato. HortScience 25:1255-1257.

$\emptyset y d v i n$, J. 1984. Features of evolution of the garden strawberry, Fragaria $\times$ ananassa Duch. from wild Fragaria-species. II. Comparisons of seed number and size. Relationships between fruit size and seed number. Meldinger Fra Norges Landbrukshøgskole 62:1-12.

Sattler, R. 1973. Fragria vesca L. (strawberry), p. 72-77. In: R. Sattler (ed.) Organogenesis of flowers. Univ. Toronto Press, Toronto.

Sinnott, E. 1939. A developmental analysis of the relation between cell size and fruit size in cucurbits. Amer. J. Bot. 26:179-189.

Sjulin, T.M. and B.H. Barritt. 1984. 'Tillikum' day-neutral strawberry. HortScience 19:452-453.

Smith, V.H. 1950. Cell-multiplication and cell-enlargement in development of flesh of apple fruit. Ann. Bot. 14:22-38.

Strik, C.B. and J.T.A. Proctor. 1988. Relationship between achene number, achene density, and berry fresh weight in strawberry. J. Amer. Soc. Hort. Sci. 113:620623.

Szczesniak, A.S. and B.J. Smith. 1969. Observations on strawberry texture: A threepronged approach. J. Texture Studies 1:65-89.

Takeda, F.. G.W. Lightner, and B.L. Upchurch. 1990. A rapid method of determining carpel numbers in strawberry flowers. HortScience 25:230.

Webb, R.A., J.V. Purves, and B.A. White. 1974. The components of fruit size in strawberry. Scientia Hort. 2:165-174

Wenzel, W.G. and C.W.J. Smith. 1974. Berry development in a number of strawberry (Fragaria $\times$ ananassa) cultivars. Agroplantae 6:65. 